\title{
The Legal Nature of Decisions of Constitutional Courts of Russia and Foreign Countries and Investigating its Psychological Consequences
}

\section{La naturaleza jurídica de las decisiones de los tribunales constitucionales de Rusia y países extranjeros y la investigación de sus consecuencias psicológicas}

\author{
Evgeniy E. Tonkov* ${ }^{(D)}$ \\ Belgorod State University, Belgorod, Russia \\ ORCID: https://orcid.org/0000-0002-0031-374X \\ Natalya A. Kosolapova \\ Belgorod State University, Belgorod, Russia \\ ORCID: https://orcid.org/0000-0002-2044-160X \\ Valeria P. Lebedinskaya \\ Yessentuki Institute of Management, Business and Law, Yessentuki, Russia \\ ORCID: https://orcid.org/0000-0003-4480-306X \\ Shadid Sh. Mutsalov \\ Chechen State University, Grozny, Russia \\ ORCID: https://orcid.org/0000-0001-9312-8457 \\ Olga V. Stulnikova \\ Penza State University, Penza, Russia \\ ORCID: https://orcid.org/0000-0001-5327-1240
}

Received 12-12-19 Revised 01-25-20 Accepted 04-14-20 On line 04-21-20

*Correspondence

Email: etonkov@bsu.edu.ru
Cite as:

\footnotetext{
Tonkov, E. E., Kosolapova, N. A., Lebedinskaya, V. P., Mutsalov, S. Sh., \& Stulnikova, O. V. (2020). The Legal Nature of Decisions of Constitutional Courts of Russia and Foreign Countries and Investigating its Psychological Consequences. Propósitos y Representaciones, 8(2), e508. doi: http://dx.doi.org/10.20511/pyr2020.v8n2.508
} 


\section{Summary}

The authors, on the basis of the importance of the activities of constitutional courts in the system of separation of powers in most countries, propose a comparative legal analysis of the normative and legal acts governing the procedure for the adoption and legal nature of decisions of these bodies. On the basis of the study of the legal consolidation of the activities of the constitutional courts, it was concluded that the decisions of the constitutional courts, possessing such characteristics as the possibility of abolishing the legal norm; the final character; the obligation of execution for all state authorities, organizations and citizens; and the moral authority, perform a law-making function, establish rules governing important relations in society and play a special role in ensuring and protecting fundamental human and civil rights and freedoms plays an important role in ensuring and protecting fundamental human and civil rights and freedoms and constitutions of the countries considered in this article.

Keywords: Constitutional Court; Judgment; Legal Acts; Judicial System; Judicial Authority; Constitution.

\section{Resumen}

Los autores, sobre la base de la importancia de las actividades de los tribunales constitucionales en el sistema de separación de poderes en la mayoría de los países, proponen un análisis jurídico comparativo de los actos normativos y legales que rigen el procedimiento para la adopción y la naturaleza jurídica de las decisiones de estos cuerpos. Sobre la base del estudio de la consolidación jurídica de las actividades de los tribunales constitucionales, se concluyó que las decisiones de los tribunales constitucionales, que poseen características tales como la posibilidad de abolir la norma legal; el personaje final; la obligación de ejecución para todas las autoridades estatales, organizaciones y ciudadanos; y la autoridad moral, desempeñar una función legislativa, establecer reglas que rijan las relaciones importantes en la sociedad y desempeñar un papel especial en garantizar y proteger los derechos y libertades humanos y civiles fundamentales desempeña un papel importante en garantizar y proteger los derechos y libertades humanos y civiles fundamentales y constituciones de los países considerados en este artículo.

Palabras clave: Tribunal Constitucional; Sentencia; Actos Legales; Sistema Judicial; Autoridad Judicial; Constitución.

\section{Introduction}

The main task in the establishment of constitutional courts is to establish a specialized body of the judiciary to ensure the implementation of the Constitution, which goes beyond the traditional structure of the judiciary. A prime example is the Federal Constitutional Court of Germany, established in 1949 under the post-war Basic Law. Hence, constitutional courts usually represent the guarantor of constitutional protection and control (Favoreu, 1990) not only in Russia and Europe, but even under authoritarian regimes (for example, Egypt).

Apart from exercising exclusive jurisdiction over constitutional questions, there are in fact virtually no powers that all constitutional courts have in common in every country (apart from the constitutional review of legislation, and even this power is variable in its scope and effect), nevertheless, contemporary constitutional courts possess the following four main types of power (Harding, 2017):

1. Constitution-drafting jurisdiction (controlling the constitution itself): adjudicating issues arising in the constitution-making process; reviewing the constitutionality of constitutional amendments. 
2. Judicial review of legislative acts (controlling the legislature): reviewing the constitutionality of laws in advance of legislation (ante factum); reviewing the constitutionality of laws after legislation (ex post facto); reviewing the constitutionality of decisions by the legislature; initiating or requiring legislation.

3. Jurisdiction over officials and agencies (controlling the executive): reviewing the constitutionality of executive actions and decisions; hearing impeachment proceedings against holders of public office; consideration of criminal or civil cases in respect of official corruption; consideration of qualifications of individuals to hold or continue to hold public office; adjudication of appointment of office-holders under the constitution; adjudication of disputes as to the competence of organs of state; adjudication of disputes between organs of state.

4. Jurisdiction over political parties and elections (controlling elections): adjudication of the dissolution or merger of political parties and control over constitutionality of their actions; examining the legality of elections and election results at any level; hearing electoral petitions.

Note also that no one country has constitutional court which possesses all four of these powers. Notwithstanding the various combinations of the above-mentioned powers, in every civil law country all decisions of constitutional courts shall enter into force immediately upon proclamation, be effective directly and not require confirmation by other bodies or officials.

Therefore, the concept of the essence and legal nature of decisions of constitutional courts in Russia and foreign countries is of scientific interest and makes it possible to better understand the content of the activities of these judicial bodies.

\section{Methods}

In the process of writing the article, various methods were used: system, analysis and synthesis, logical and other popular scientific methods, as well as a number of private scientific methods. Thus, the use of the method of comparative legal study has made it possible to reflect foreign experience in the legal regulation of constitutional proceedings.

Legal material on the interpretation of the legal aspects of decisions of constitutional courts has been analyzed and consolidated by means of the formal-legal method. Still the use of methods of specific socio-legal and comparative-legal research has made it possible to reflect both Russian and foreign experience in the application and interpretation of court decisions in constitutional judicial proceedings. Reliance on statistical, sociological and other methods of knowledge was also required to further argue and illustrate relevant constitutional and legal provisions.

The use of methods of analysis of legal terminology revealed a meaningful aspect of the decisions of constitutional courts in the context of the evolution of the modern legal system (Harding, 2017).

\section{Results and Discussion}

The legal nature of decisions of constitutional courts depends directly on the establishment of the very procedure for constitutional proceedings. Thus, in foreign practice, the regulation of constitutional proceedings, as well as of classical proceedings, falls within the competence of the legislator, in most cases organic (for example, Germany, Spain, France, Italy) (Turanin, Tonkov, Kuprieva, Pozharova, \& Turanina, 2019). The independence of constitutional justice bodies from other bodies of state power in determining the rules of their own organization and functioning largely determines the specificity of the decisions taken by them. It is not possible to consider all countries in detail in this article, so we will focus on a few examples. 
The German Constitutional Court, the Bundesverfassungsgericht, was the first entirely new constitutional jurisdiction established in postwar Europe. The cassation function of the procedure of constitutional complaint remains less articulated: more significant is the "persuading" or "directing" function whereby the Court rules on the manner of interpretation and application of a particular fundamental right, and the specialized jurisdictions follow the Court voluntarily. Thus, the direct application of the Constitution (of its provisions on fundamental rights) is present in the decisions of all the courts and judges. The Constitutional Court, while preserving the last word if a controversy arises, no longer claims a monopoly over application of the Constitution but, rather, acts as a coordinator of that process (Kosolapova, Kalmanova, Samsonov, Vanyan, \& Zejnalova, 2018).

The Constitutional Court operates on the basis of the Constitution, the Federal Constitutional Court Act (Garlicki, 2007) adopted in 1951 (with subsequent amendments, in particular 1969, 1993) and its regulations (adopted in 1986 and revised in 1989). The court works continuously. One of the chambers is headed by the President of the Court and the other by the Deputy. Decisions are usually made by a majority vote. If the votes split equally, the case is dismissed.

It is important to emphasize that cases are mostly dealt with in writing. The court has the right to organize an oral hearing if the parties do not object. Individual complaints may not require oral hearings, and the consideration of such cases is organized in writing. By the way, individual complaints may be submitted within 1 month after the adoption of the court decision or the contested act. When the law is appealed, the term is 1 year. The Act stipulates that an individual complaint may be submitted to the Constitutional Court only when all other judicial possibilities have been exhausted. The law also requires parties to be represented by lawyers before the Court.

As to the nature of the Court 's decisions, The Constitutional Court may consider the legal norm null and void, but the same decision may have retroactive effect. At the same time, the Court may find that the legal norm is not in conformity with the Constitution, in which case the norm remains in force until its revision by the legislator. The Constitutional Court may determine a time limit for review (paragraphs 31 and 79 of the Constitutional Court Act). The Constitutional Court may also invalidate a decision of a court of general jurisdiction and refer the case to another Court (as a rule, the Constitutional Court does not rule in cases of ordinary courts).

According to article 1 of Federal Constitutional Law on the Constitutional Court of the Russian Federation, the Constitutional Court of the Russian Federation shall be the judicial body of constitutional review, exercising judicial authority autonomously and independently, by means of constitutional judicial proceedings (Gesetz über das Bundesverfassungsgericht vom 12, 1951).

The decision of the Constitutional Court of the Russian Federation is final and is not subject to appeal. Decisions of the Constitutional Court of the Russian Federation, as well as decisions of the normative body, essentially have the same scope of effect in time, space and circle of persons. Consequently, the same general meaning as normative acts is not inherent in the law enforcement acts of other courts (Decision of the Constitutional Court of the Russian Federation of 16 June 1998 No. 19-P).

Decisions taken in the course of constitutional proceedings (decisions, opinions, determinations) have special legal consequences. As a result of the Constitutional Court 's examination of the case, a normative act or treaty or certain provisions thereof may be found to be in conformity with or inconsistent with the Constitution. In disputes on competence, the Constitutional Court has the right to confirm or deny the authority of the relevant body to publish an act or to perform an act of a legal nature that gave rise to a dispute on competence. Acts or their individual provisions declared unconstitutional are null and void, i.e. they cannot be applied. International treaties not in conformity with the Constitution of the Russian Federation that have not entered into force for the Russian Federation are not subject to introduction and application. 
Decisions of courts or other bodies based on acts declared unconstitutional are not enforceable and must be reviewed in cases established by federal law (Federation, 2017).

It should be noted that the question of the legal nature of acts of the Constitutional Court is debatable: some consider these acts as sources of law, others do not recognize them as such. This discussion is a manifestation of the general discussion of the judgment as a case law. Many experts speak about recognition of precedent as a source of law in the Russian legal system (Demidov, 1998; Guk, 2003; Marhgejm \& Kosolapova, 2019).

The Constitutional Court of the Russian Federation does not reproduce in its decisions the arguments of both parties on the issues before it, as other courts do. As a rule, the decision of the Constitutional Court summarizes only the complainant 's position on the issue under consideration. Almost never does the Court indicate the position of the other party (Rarog, 2001).

The Constitutional Court of the Republic of Lithuania shall guarantee the supremacy of the Constitution of the Republic of Lithuania in the legal system as well as the constitutional legality by deciding, according to the established procedure, whether the laws and other acts adopted by the Seimas are not in conflict with the Constitution and whether acts of the President of the Republic and the Government are not in conflict with the Constitution or laws. According to article 59 rulings of the Constitutional Court shall be final and not subject to appeal (Didy`k, 2013).

Only the Constitutional Court of the Republic of Lithuania may officially interpret its own ruling, conclusion, or decision at the request of the persons that participated in the case, of other institutions or the persons or on its own initiative. Regarding the interpretation of a ruling, conclusion, or decision of the Constitutional Court, a judicial hearing shall be held in a free form. The parties to the case shall be notified about the date and place of such a hearing. A decision concerning the interpretation of a ruling, conclusion, or decision of the Constitutional Court shall be adopted at the Constitutional Court's hearing as a separate document. It shall be sent and published pursuant to the procedure established by this Law.

The Constitutional Court of the Republic of Lithuania must interpret its ruling, conclusion, or decision without changing their contents.

As for the Review of Rulings, Conclusions, and Decisions of the Constitutional Court of the Republic of Lithuania, it may review its rulings, conclusions, and decisions on its own initiative if new, essential circumstances turn up which, if they had been known to the Constitutional Court at the time when such rulings, conclusions, and decisions were adopted, they could have determined a different content of the passed ruling, conclusion, or decision. In such a case, the Constitutional Court shall adopt a decision and start the consideration of the case anew. A decision of the Constitutional Court of the Republic of Lithuania concerning the interpretation of its ruling, conclusion, or decision may also be reviewed if the ruling, conclusion, or decision was not interpreted according to its actual content.

In Slovenia the Constitutional Court is an independent and autonomous state authority which carries out constitutional review - it is the highest body of the judiciary for the protection of human rights and fundamental freedoms and a guardian of constitutionality and legality. In relation to other state authorities, the Constitutional Court is an autonomous and independent state authority (Law on the Constitutional Court of the Republic of Lithuania). Also the decisions of the Constitutional Court are binding. But despite the fact that the Constitutional Court decisions contain a statement of reasons when so determined by law, the Constitutional Court of Slovenia does not provide any additional explanation of its decisions.

The Constitutional Court of Italy is Corte Costituzionale. It should be noted that there is no individual complaint procedure, but a system is in place through "legal questions" submitted 
to the Court by the courts of general jurisdiction. Such appeals may relate only to those legislative provisions that would form the basis of the court 's decision in the case in question. Once such a question is brought, the Constitutional Court decides on the constitutionality of the provision referred to, and the Court 's ruling becomes part of the law of the case. However, since its early years, the Constitutional Court has tried to avoid decisions of unconstitutional nature. Rather than invalidating the laws, the Court sought to develop so-called interpretative decisions in which the constitutionality of a right was decided not in absolute terms but in relation to a specific interpretation of the provision (Kosolapova, Kalmanova, Samsonov, Vanyan, \& Zejnalova, 2018; Constitutional Court Act of Slovenia). But this interpretation by the Constitutional Court of law may differ from that traditionally adopted in the jurisprudence of ordinary courts, which in turn may call into question the powers of the Constitutional Court.

\section{Conclusion}

Proceeding from the aforesaid, it is possible to select the following provisions affecting the special status of decisions of the constitutional courts (Harding, 2017): 1) the constitutional court in the decisions is obliged to keep independence, despite any pressure from other branches of the power, institutions, mass media, society or the separate interested groups; 2) the constitutional court has to show an initiative in explanation of the role and the decisions to society, realizing their public perception and the importance; 3 ) the constitutional court has to be consecutive in the decisions and moderate in use of the judicial remedies which are available at its order, acting at the same time as the strongest democratic mechanism and providing respect for the rights and freedoms of citizens and human rights in general.

Thus, decisions of the constitutional courts, having such signs as the possibility of cancellation of precept of law; the final character; the obligation of execution for all public authorities, the organizations and citizens; and the moral authority, perform law-making function and establish the rules governing the important relations in society.

\section{References}

Constitutional Court Act of Slovenia. Official Gazette of the Republic of Slovenia, 64/07.

Demidov, V. V. (1998). O roli i znachenii postanovlenij Plenuma Verxovnogo Suda Rossijskoj Federacii. Byulleten`Verxovnogo Suda Rossijskoj Federacii, 3 (in Russian)

Didy`k E`, M. (2013). Predstavitel`stvo advokatom interesov doveritelya v konstitucionnom sudoproizvodstve. Aktual 'ny `e problemy` rossijskogo prava, 12. (in Russian)

Favoreu, L. (1990). Constitutional review in Europe. Constitutionalism and Rights: The Influence of the United States Constitution Abroad, pp. 38-62.

Federation, R. (2017). Federal Constitutional Law on the Constitutional Court of the Russian Federation. http://www.ksrf.ru/en/Info/LegalBases/FCL/Documents/Law.pdf.

Garlicki, L. (2007). Constitutional courts versus supreme courts. International Journal of Constitutional Law, 5(1), 44-68.

Gesetz über das Bundesverfassungsgericht vom 12. (1951). März 1951 [Statute on the Federal Constitutional Court in the version of 12 March 1951]

Guk, P. A. (2003). Sudebny`j precedent kak istochnik prava. Penza. (in Russian)

Harding, A. (2017). The Fundamentals of Constitutional Courts. Constitutional Brief. International IDEA (Institute for Democracy and Electoral Assistance). https://www.idea.int/sites/default/files/publications/the-fundamentals-of-constitutionalcourts.pdf.

Harding, A. (2017). The Fundamentals of Constitutional Courts. International IDEA Constitution Brief.

Kosolapova, N., Kalmanova, A. B., Samsonov, V., Vanyan, K., \& Zejnalova, M. (2018). Regulations of the constitutional proceedings in foreign countries. Herald National Academy of Managerial Staff of Culture and Arts, 2(2), 119-121. 
Law on the Constitutional Court of the Republic of Lithuania. https://www.lrkt.lt/en/about-thecourt/legal-information/the-law-on-the-constitutional-court/193

Marhgejm, M. V., \& Kosolapova, N. A. (2019). Pravo na kvalificirovannuyu yuridicheskuyu pomoshh $\mathrm{v}$ konstitucionnom sudebnom processe: monografiya. M.: Izdatel`skij dom «Yur-VAK» (in Russian)

Rarog, A. I. (2001). Pravovoe znachenie raz“yasnenij Plenuma Verxovnogo Suda RF. Gosudarstvo i pravo, 2. (in Russian)

Turanin, V. Y., Tonkov, E. E., Kuprieva, I. A., Pozharova, L. A., \& Turanina, N. A. (2019). Legal terminology phenomenon in the context of modern legal system evolution. Humanities \& Social Sciences Reviews, 7(4), 1291-1295. 